\title{
2.1. Dostępne przedszkole, dostępna szkoła - co to znaczy?
}

DOI: $10.47050 / 65591838.108-123$

Grażyna Małachowska, Marek Tarwacki

Autorzy niniejszego rozdziału - dyrektorzy placówek edukacyjnych - omawiają z perspektywy praktyków kwestie budowania instytucji edukacyjnych dostępnych dla wszystkich, dbających o prawidłowy rozwój wychowanków i dostosowujących się do zmian zachodzących w świecie. Analizują rolę kadry kierowniczej oraz pracowników przedszkola i szkoły w procesie realizacji założeń edukacji włączającej. Wskazują również warunki niezbędne do odniesienia sukcesu przez wszystkich uczniów (strategie rozwoju, plany pracy).

\section{Słowa kluczowe:}

edukacja włączająca 


\subsection{Inclusive preschool, inclusive school - how to understand it?}

DOI: $10.47050 / 65591838.108-123$

Grażyna Małachowska, Marek Tarwacki

The authors of this chapter - directors of educational institutions

- present a practical view on the issue of building educational institutions accessible to all, caring for the proper development of wards and adapting to changes in the world. They analyze the role of the management and employees of kindergarten and school in the process of implementing inclusive education assumptions and indicate the conditions necessary for success of all students (development strategies, work plans).

\section{Keywords:}

inclusive education

diversity management

preschool/school development strategy 


\section{Dostępne przedszkole - co to znaczy?}

Zmiany zachodzące we współczesnym świecie, ich wielość i intensywność powodują, że coraz bardziej wpisują się one w codzienność edukacji, warunkują jej rozwój, wskazują na szeroką perspektywę oddziaływań oraz wpływają na jej koloryt społeczny. Wyjście naprzeciw tym zmianom to zadanie dostępnego przedszkola, koncentrującego się na stworzeniu takich warunków, które zapewnią dzieciom sukces przy przekraczaniu kolejnego progu edukacji oraz umożliwią korzystanie z dobrodziejstw otaczającego nas świata, a w konsekwencji osiąganie życiowych celów. Dostępność to przede wszystkim otwartość na różnorodność oraz świadomość jej znaczenia dla rozwoju każdego uczestnika procesu dydaktycznego. Musi być upodmiotowiona, "uczłowieczona", oparta na empatii, dialogu i współpracy, skierowana na jednostkę oraz na wspólnotę, w której ta jednostka funkcjonuje. Dostępne przedszkole dostosowuje się do dziecka, a nie odwrotnie. Jest to miejsce przyjazne i bezpieczne, oferujące wysokie standardy edukacyjne i moralne, w którym znaczenie mają takie wartości, jak miłość, mądrość i wolność.

Miłość jest bezwarunkowa, zajmuje najważniejsze miejsce w naszym życiu. Oznacza tolerancję, akceptację i poczucie bezpieczeństwa. To także szacunek dla drugiego człowieka, uznanie jego odmiennych wyborów oraz wspieranie podejmowanych działań. Wiąże się również z bezwarunkową gotowością do niesienia pomocy. Mądrość kojarzy się z takimi pojęciami jak: doświadczenie, rozumienie, wiedza. Jest to świadomość siebie i otaczającego nas świata, jego bogactwa i różnorodności, a także potrzeba ciągłego rozwoju, konsekwencja w działaniu. Mądrość pozwala także odróżniać dobro od zła. Wolność to świadomość własnej tożsamości, miejsca w społeczeństwie, prawa do bycia innym, umiejętność dokonywania wyborów oraz ponoszenia za nie odpowiedzialności. Wolność oznacza również możliwość popełniania błędów. Wiąże się z godnością, niezależnością emocjonalną i radością życia. Wszystkie te wartości stanowią o człowieczeństwie „ludzi bogatych wewnętrznie, świadomych w całej pełni odpowiedzialności za czyny i słowa swoje, z wykrystalizowaną wobec zjawisk życia postawą i spiżowym nakazem wewnętrznym" (Grzegorzewska 2002). 
Dostępność jest nierozerwalnie powiązana z włączaniem, począwszy od pierwszego etapu edukacyjnego. W przedszkolu otwartym włączanie jest czymś naturalnym, nie zaś działaniem chaotycznym i pozbawionym reguł. Naturalnym, bo wynika z głębokiego przekonania wszystkich uczestników procesu o słuszności idei inkluzji, z obszernej wiedzy nauczycieli oraz z poczucia odpowiedzialności za każdego wychowanka. Proces ten jest oparty na empatii i konsekwencji. Odpowiednia mentalność, ale także określony sposób myślenia, kultura, charyzma i odwaga - to elementy, które po wdrożeniu w praktykę przedszkolną dają pozytywne rezultaty.

Moje rozumienie edukacji włączającej skupia się na realizowaniu prawa do bycia z innymi, przy jednoczesnym dostrzeganiu własnej odmienności. Często słyszę pytanie: „lle dzieci w pani przedszkolu jest objętych działaniami włączającymi?", na które odpowiadam krótko: „Wszystkie". Każde bowiem z nich to osobny byt, wymagający szczególnej opieki i wsparcia. Jest to niepowtarzalna indywidualność, niezwykle skomplikowana i tajemnicza, zasługująca na odkrycie i uwagę, mająca takie samo jak inni prawo do edukacji. Wykluczenie jest w każdym z nas, nieświadomie pielęgnujemy je, chociaż nie akceptujemy, boimy się go, ale nie odrzucamy, jest nam bowiem potrzebne do zrozumienia różnorodności. Dlatego bliska jest mi teza, że: „Inkluzja jest czymś więcej niż integracją" (John, Baylis 1994). Jest to przejście od tolerancji do akceptacji, dostrzeżenie w sobie "innego", ale nie "obcego". W edukacji oznacza pełne uczestnictwo dziecka w procesie uczenia się, z uwzględnieniem jego indywidualnej historii oraz specjalnych potrzeb. Włączenie jest więc pojęciem o szerszym znaczeniu niż integracja-działaniem perspektywicznym i systematycznym, skierowanym na dziecko, a nie na program, wymagającym nowego spojrzenia na współczesne przedszkole. Żeby mogło się ono dokonywać, „szkoła jako całość musi się zmieniać w taki sposób, by zapewniała dostęp do pełnego zakresu szans edukacyjnych i społecznych wszystkim uczniom" (Mittler 2000).

Podsumowując, dostępność to „wrota do włączania", to świadomość i akceptacja różnorodności, która jest istotą naszej tożsamości. Bycie „innym" i wśród „innych" to sedno naszej egzystencji, droga do poznania prawdy o sobie samym. "Inny" jest więc nam niezbędny do istnienia. Takie przesłanie powinniśmy przekazać dzieciom, zarówno poprzez własną postawę, jak i przez konkretne działania edukacyjne. 


\section{Dostępna szkoła - co to znaczy?}

Obecnie szkoła funkcjonuje $w$ dynamicznie zmieniającej się rzeczywistości, co ma związek nie tylko z procesem wprowadzania reform. Staje się ona miejscem, gdzie spotykają się różne oczekiwania, zarówno zewnętrzne, jak i wewnętrzne. Istotną rolę w osiągnięciu lepszych wyników i warunków nauki odgrywają zmiany, jakie zachodzą wewnątrz placówki. Ta, która jest świadoma swojego potencjału, staje się samoczynnie „bąblem zmiany” (Dudzikowska 2001, s. 137-138). Dostępność i otwartość oznaczają prowadzenie szerokiego dialogu przez wszystkie strony społeczności szkolnej, a także ciągłe dokształcanie się i doskonalenie umiejętności w zakresie zarządzania i edukowania. Szkoła powinna być kojarzona $z$ tym, co najlepsze: profesjonalizmem w nauczaniu, rodzinną atmosferą, bezpieczeństwem, tolerancją. W centrum uwagi i wszelkich działań musi znajdować się dziecko z jego potrzebami i oczekiwaniami. Skoro w społeczeństwie coraz bardziej zaczyna się liczyć inicjatywa, odpowiedzialność, samorealizacja, to szkoła powinna wszechstronnie przygotować wychowanków do dorosłego życia. Edukacja włączająca daje równe szanse wszystkim uczniom w procesie nauczania i wychowania, zmierzając do pełnej dostępności. W takiej szkole jest miejsce na wielkie poszukiwania, eksperymenty i samodzielną pracę badawczą. Dzięki temu placówka znajdzie się bliżej uczniów, zapewniając im wysoki poziom nauczania i wychowania, propagując samorządność i postawy twórcze, dbając o każdego podopiecznego i jego wszechstronny rozwój. Dostępność to "oferta" wychowawcza szkoły, rodziców i innych osób dorosłych, powinna być więc najwyższej jakości: atrakcyjna, pełna radości, niosąca głęboką prawdę o życiu. Niczego, co piękne i wartościowe, nie może w niej zabraknąć. Oznacza możliwość przebywania, kształcenia się, wychowywania w miejscu, do którego uczęszczają siostra, brat, przyjaciel oraz rówieśnicy z sąsiedztwa. Placówka dostępna zapewnia uczniom wszechstronną edukację i bezpieczeństwo, jej zasadami są perfekcjonizm i sumienność, ciągłe kształcenie i dokształcanie, konsekwencja w działaniu. Podejmowane w szkole działania są spójne i skuteczne, zaspokajają potrzeby wszystkich uczestników procesu edukacyjnego. Uczniowie dostają równe szanse, co wynika ze zrozumienia jednostkowych potrzeb każdego z nich. Dzięki temu następuje zmiana w wielu obszarach funkcjonowania szkoły: w procesie uczenia się, nauczania, wychowania, a także we wzajemnych relacjach na linii nauczyciel - uczeń, nauczyciel 
- rodzic. W placówce włączającej żadne dziecko nie jest odizolowane od swojego naturalnego środowiska. Korzysta z bogactwa relacji, emocji komunikowania się, przyswajania wartości, naśladowania wzorcowych zachowań. Szkoła dostępna to także nauczyciele, którzy mają możliwość osobistego i zawodowego rozwoju w zakresie wykorzystywania różnych form i metod nauczania, tworzenia indywidualnych planów i programów edukacyjnych oraz wdrażania pracy zespołowej.

\section{Dyrektor przedszkola jako lider zarządzania różnorodnością}

Struktura organizacyjna i funkcjonowanie przedszkola są zdeterminowane przez różnorodne czynniki, zarówno zewnętrzne, jak i wewnętrzne, m.in. położenie, otoczenie kulturowe, środowisko lokalne i możliwości współpracy z nim, bazę i jej zasoby (w tym personel), społeczności wychowanków i ich rodziny. "Zarządzanie różnorodnością jest elementem tworzenia kapitału intelektualnego organizacji, ponieważ ludzie wykorzystują w swojej pracy ważne dla organizacji zasoby niematerialne: wiedzę, kompetencje, zdolności i doświadczenie" (Walczak 2011, s. 16). Dla dyrektora - przywódcy edukacyjnego - jest to nie lada wyzwanie oraz ogromna odpowiedzialność, z czego powinien zdawać sobie sprawę, przyjmując rolę lidera. Świadomość różnorodności, jej znaczenia w rozwoju człowieka, odpowiedzialność za każdy byt tworzący społeczność przedszkolną oraz dążenie do wysokiej jakości edukacji to pierwszy krok ku partycypacyjnemu modelowi zarządzania. Partycypacja to proces służący budowie przedszkola włączającego, dostępnego, opartego na ludziach, ich potencjale osobowościowym i intelektualnym, wzajemnym zaufaniu oraz chęci ciągłego uczenia się. Oznacza pełną identyfikację z misją i wizją placówki, współpracę, uczestniczenie i współdecydowanie, odpowiedzialność oraz refleksję wszystkich członków wspólnoty, w centrum której jest dziecko. Uwzględnia także zarządzanie przez wartości, świadomość ich źródeł oraz ich implementację na grunt społeczności przedszkolnej. Dzięki takiemu podejściu budowana jest wyjątkowość placówki, jej marka i pozycja w środowisku lokalnym. Nie chodzi tutaj o rankingi i niezdrową rywalizację, lecz o wysokie standardy edukacyjne, które dotyczą każdej jednostki, wszystkich członków zespołu i całej grupy.

Zarządzanie różnorodnością jest jednoznaczne z akceptacją tej idei i funkcjonowaniem w niej. Oznacza tworzenie miejsca bezpiecznego, odpowiadającego potrzebom wszystkich dzieci, także tych, które są 
szczególnie narażone na wykluczenie i marginalizację, w tym: niepełnosprawne, z doświadczeniem migracji, z zaburzonym zachowaniem, ofiary przemocy, sieroctwa, ubóstwa lub przewlekle chore (np. z cukrzycą, padaczką, zespołem FAS, nowotworami).

Nie można zapominać także o tym, że dyrektor-lider jest jednocześnie wychowawcą oraz nauczycielem, a także inspiratorem i koordynatorem procesu wychowawczego, dydaktycznego i opiekuńczego. Trudno wyobrazić sobie dobrego dyrektora, który nie pielęgnuje w sobie wartości humanistycznych, człowieczeństwa, który nie uczestniczy w ciągłym procesie uczenia się, który zachęca do innowacji, nie będąc innowatorem, lansuje postęp pedagogiczny, choć sam się nie doskonali, wymaga od innych, ale nie od siebie. Ważne jest również, by jego myślenie o przedszkolu miało charakter perspektywiczny, aby zawierało gen kontynuacji, bo tylko takie podejście pozwala na zbudowanie placówki „długowiecznej”.

To przez partycypację, mentoring, działania menadżerskie, kreatywną postawę i otwartość na wszelkie nowatorstwo, dyrektor-lider może stworzyć „przedszkole dostępne”, nowoczesne i bezpieczne, którego atutem są nie tylko szczęśliwe, samodzielne, twórcze dzieci czy zadowoleni rodzice, ale także wyspecjalizowana, kompetentna oraz zmotywowana do działania kadra.

\section{Dyrektor szkoły jako lider zarządzania różnorodnością}

Dyrektor, jako lider zarządzający różnorodnością, powinien być wzorcem nauczyciela i wychowawcy. Musi dbać szczególnie o przełamywanie bariery na linii nauczyciel - uczeń, nauczyciel - dyrektor, dyrektor - rodzic. Więzi między tymi osobami decydują o jakości procesu kształcenia i wychowania (Kwiatkowski 2010, s. 15-19). Różnorodność to podstawa budowania prawidłowych zachowań oraz eksponowania wartości edukacyjnych i wychowawczych.

Przywództwo w edukacji wpisuje się idealnie w trzy podstawowe komponenty więzi moralnej: zaufanie, lojalność, solidarność (Sztompka 2004, s. 187).

Zadaniem lidera jest tworzenie odpowiednich warunków, aby placówka robiła postępy w integracji społecznej, dydaktyce i wychowaniu. Powinien on dążyć do zacieśnienia współpracy w procesie planowania, monitorowania działań oraz finansowania między wszystkimi podmiotami mającymi bezpośredni wpływ na funkcjonowanie szkoły. 
Kadra, którą zarządza, powinna mieć możliwość kształcenia i samokształcenia umiejętności wykorzystywania form i metod nauczania, tworzenia indywidualnych planów i programów edukacyjnych, a także zespołowej pracy (Tarwacki 2015, s. 2). Sprzyja to osobistemu podejściu do ucznia, do oceny jego możliwości, a także wzmocnieniu uzdolnień. Dostrzeganie mocnych i słabych stron ucznia umożliwia pełne włączanie go w system edukacyjny. W placówce powołuje się zespoły, w skład których wchodzą wychowawcy nadzorujący cały proces dydaktyczno-wychowawczy, oraz zespoły specjalistów, których zadaniem jest realizacja zaleceń zapisanych w orzeczeniach i opiniach poradni psychologiczno-pedagogicznych, jak również pomaganie nauczycielom (dydaktykom) w bezpośredniej pracy z uczniem.

Lider szkolny czuwa nad całościowym wdrażaniem pomocy specjalistycznej oraz dydaktyczno-wychowawczej. Dostrzega potrzebę osiągnięcia nowej jakości przez współpracę z samorządem lokalnym i organizacjami pozarządowymi. Staje się przywódcą w procesie budowania partnerstwa i pozyskiwania środków zewnętrznych. Ta część funkcjonowania placówki daje nowe przestrzenie i możliwości kontynuacji rozpoczętych przez nią projektów. Działania dyrektora jako lidera umożliwiają szersze otwarcie szkoły - aby była nie tylko instytucją przekazującą wiedzę, analizującą zestawienia i wyniki punktowe, ale również miejscem, w którym wsparcie otrzyma każdy uczeń (także taki, który w żadnych rankingach nie jest uwzględniany).

Dobrym liderem jest dyrektor, który wprowadza do procesu nauczania nowe idee: planowanie lekcji uwzględniających różne potrzeby uczniów, rozwijanie umiejętności dostrzegania i rozumienia różnic, angażowanie uczniów w samodzielne uczenie się, obserwację lekcji i zajęć specjalistycznych, poszukiwanie odpowiednich zadań, z którymi muszą zmierzyć się uczniowie, kształcenie umiejętności współpracy. Dyrektor musi mieć przekonanie, że im wcześniej wesprze się dziecko ze specjalnymi potrzebami, tym większe jest prawdopodobieństwo osiągnięcia sukcesu edukacyjnego.

Wsparcie powinno być całościowe - obejmować nie tylko ucznia, ale także jego rodzinę. Rodzic jest pierwszym "terapeutą" swojego dziecka, dlatego ważne jest, aby został dokładnie wysłuchany i potraktowany jako osoba niezbędna w procesie kształcenia. Mówiąc o uczniu ze specjalnymi potrzebami, dyrektor-lider pamięta również o jednostkach wybitnie utalentowanych. Wymaga to od szkoły za- 
stosowania dodatkowych narzędzi, tzn. odpowiednich metod i form pracy, zajęć dodatkowych, pomocy asystenta, właściwych pomocy dydaktycznych i technicznych. Pod kierownictwem lidera, który jest pasjonatem, szkoła dąży do wspierania rozwoju każdego dziecka, biorąc pod uwagę wszystkie aspekty tego procesu: emocjonalny, poznawczy, twórczy, społeczny, fizyczny, moralny. Uczniowie są traktowani indywidualnie. Jedni wymagają większego wsparcia emocjonalnego, kolejnym potrzebna jest pomoc $w$ nauce czy dostosowanie materiału do ich możliwości, a inni wymagają odpowiedniego sprzętu technicznego i konkretnej infrastruktury: aparatów słuchowych, programów do powiększania tekstu, ułatwień architektonicznych.

Zadaniem dyrektora jest rozpoznanie tych potrzeb i wspieranie działań służących ich zaspokojeniu. W proces ten angażuje całą kadrę pedagogiczną, czyli nie tylko specjalistów, ale także nauczycieli poszczególnych przedmiotów i wychowawców. Jest to stała współpraca, w ramach której wszyscy biorą odpowiedzialność za każde dziecko w klasie. Dyrektor stara się patrzeć na swoich uczniów twórczo i konstruktywnie. Rozważa, co należy zmienić w metodach, wymaganiach w pracy, aby wyeliminować niepowodzenia ucznia i znaleźć sposoby na naprawę sytuacji. Dzieli się spostrzeżeniami dotyczącymi postępów danego podopiecznego - co zwiększa otwartość, chęć współpracy i wzajemne wspieranie się kadry szkolnej i uczniów w osiąganiu celów edukacyjnych i wychowawczych. Warto $w$ tym miejscu zauważyć różnicę między zaufaniem do poziomu dydaktycznego szkoły, a zaufaniem do kształtowanego w niej systemu wartości (Szymański 1998, s. 9-10). Placówka pod kierownictwem dyrektora-lidera nie jest zawieszona w próżni - współpracuje $z$ instytucjami lub $z$ organizacjami pozarządowymi w celu podniesienia jakości pracy. Sprzyja to trafnej identyfikacji potrzeb społecznych.

\section{Strategie rozwoju przedszkola}

Tworzenie strategii rozwoju przedszkola dostępnego, ukierunkowanej na "włączanie", wymaga od dyrektora świadomości ciągłości tego procesu, elastyczności, gotowości do zmian (niejednokrotnie pojawiających się "tu i teraz"). Świadomość, jak już wcześniej wspominaliśmy, musi być osadzona w wartościach, które są absolutnymi determinantami myślenia strategicznego. Patrząc w przyszłość, nie można negować przeszłości - trzeba korzystać z tego, co się sprawdziło, a jednocześnie 
uwzględniać nowe perspektywy rozwojowe. Dynamika współczesnej cywilizacji i jej rosnąca złożoność wymagają od nas wykorzystania nowych zasobów oraz ciągłego uczenia się. Te elementy są niezbędne do rozumienia i odczytywania zmieniających się warunków życia, umożliwiają także sprostanie nowym wyzwaniom. Pozwalają na budowanie placówki „długowiecznej", o wyraźnej tożsamości (tutaj: przedszkola włączającego). Dzięki takim zasobom można z dużym prawdopodobieństwem określić miejsce, w którym za kilka lat znajdzie się przedszkole. Taka wizja wymusza zaplanowanie sekwencji działań umożliwiających osiągnięcie zdefiniowanego celu. Dlatego efektywna strategia (koncepcja) powinna być budowana na podstawie przejrzystych, znanych całej społeczności przedszkolnej, zasad. Są to m.in.:

$\rightarrow$ partnerstwo/partycypacja (myślenie strategiczne, diagnoza, współdziałanie),

$\rightarrow$ dynamiczność (powiązana z kreatywnością i otwartością na zmiany, uwzględnia zewnętrzne szanse),

$\rightarrow$ kontynuacja (czerpanie z dobrych praktyk przedszkola oraz strategii innych podmiotów, także międzynarodowych),

$\rightarrow$ celowość i hierarchiczność (ustalenie priorytetów, celów, zadań),

$\rightarrow$ systematyczna weryfikacja (monitoring strategiczny, bieżąca aktualizacja, ewaluacja),

$\rightarrow$ działania strategiczne („działania w drodze”, wdrażanie zadań, osiąganie celów).

Tworzenie strategii/koncepcji musi być oparte na dialogu, wnikliwie przemyślane i zaplanowane w czasie, a poszczególne fazy realizacji powinny być zhierarchizowane. Poniżej przykładowe etapy planowania strategicznego obowiązujące w przedszkolu, którym kieruję:

$\rightarrow$ planowanie wstępne (m.in. powołanie zespołu do spraw koncepcji/strategii, ustalenie harmonogramu działań i sposobu przekazywania informacji w trakcie ich realizacji),

$\rightarrow$ analiza/diagnoza potrzeb (środowisko wewnętrzne, lokalne, zewnętrzne źródła informacji),

$\rightarrow$ badanie posiadanych zasobów wewnętrznych (dzieci, nauczyciele, specjaliści, pozostały personel, rodzice, sprzymierzeńcy, organizacja, finanse, zaplecze dydaktyczne),

$\rightarrow$ badanie zasobów zewnętrznych: lokalnych, ogólnopolskich, europejskich (władze oświatowe, urząd miasta, urząd gminy, 
przedszkola i szkoły podstawowe, obiekty przyrodnicze, teatry, kina, muzea, biblioteki, poradnie psychologiczno-pedagogiczne, uczelnie, fundacje, stowarzyszenia, służby mundurowe, lokalne programy na rzecz edukacji, inicjatywy międzynarodowe, np. Erasmus+),

$\rightarrow$ sformułowanie misji (jest to swoista obietnica, zespół wartości, filozofia - fundament istnienia przedszkola),

$\rightarrow$ sformułowanie wizji (pozytywny, perspektywiczny obraz przedszkola, wielu konkretnych inicjatyw i działań, które uświadamiają społeczności przedszkolnej, przez jakie etapy trzeba przejść - służy ona realizacji misji),

$\rightarrow$ określenie kierunków działań oraz celów strategicznych,

$\rightarrow$ opracowanie planu operacyjnego (roczna lub maksymalnie dwuletnia koncepcja pracy placówki, uwzględnia również przygotowanie i realizację programów wspomagania),

$\rightarrow$ wdrażanie strategii,

$\rightarrow$ monitoring i ewaluacja.

Określenie zarysu rozwojowego przedszkola należy do dyrektora- lidera, to od jego wizji zaczyna się strategia. $Z$ reguły pojawia się już w koncepcji kierowania placówką prezentowanej przez kandydata podczas konkursu. Dalej jest ciężka praca całej społeczności przedszkolnej (włącznie z liderem). Strategia jest podstawą istnienia nowoczesnej placówki - zorientowanej na przyszłość, opartej na wartościach i otwartej na różnorodność.

\section{Strategie rozwoju szkoły}

Tworząc strategie rozwoju szkoły trzeba myśleć o placówce nowoczesnej, prezentującej wysoki poziom nauczania i wychowania. Jej dewizą ma być bezpieczeństwo, tolerancja, odkrywanie sensu uczenia się, kreowanie pozytywnych wzorców do naśladowania, aktywny udział w życiu środowiska lokalnego. Celem jest wychowanie człowieka otwartego, odpowiedzialnego za siebie i innych, wrażliwego, kulturalnego i szlachetnego.

"Szkoła nie poddaje się planistom bezwarunkowo" (Warnken 1997, s. 75), dlatego w koncepcjach jej rozwoju znajduje się miejsce na poszukiwania, eksperymenty, projekty i samodzielną pracę badawczą. Takie pomysły mogą być realizowane przez zespół ludzi, którzy są otwarci na kolejne innowacyjne inicjatywy na lekcjach i poza nimi. Dobrym przy- 
kładem może być przyjmowane założenie, „że działanie nauczyciela na rzecz zmiany (w tym również zmiany rozwojowej ucznia) jest tym skuteczniejsze, im bardziej nauczyciel sam podlega procesom rozwojowym, im bardziej jest świadomy siebie, a także świadomy realizacji przez szkołę jego własnych potrzeb zawodowych (poznawczych, sprawnościowych), a także egzystencjalnych (np. uzyskania uznania, autonomii)" (Kwiatkowska 1997, s. 52). Bardzo dużą rolę w kreowaniu takich postaw odgrywają poczynania dyrektora, który w ramach sprawowanego nadzoru pedagogicznego pobudza różne formy aktywności nauczycieli i pracowników szkoły: ich samodoskonalenie zawodowe, samokształcenie, podnoszenie kwalifikacji oraz uzyskiwanie stopni awansu zawodowego, współpracę w ramach zespołów, lekcje koleżeńskie, tworzenie programów autorskich i stosowanie innowacji pedagogicznych.

Dyrektor ma do zrealizowania konkretne zadania w tym zakresie:

$\rightarrow$ stworzenie planu nauczania na dany rok szkolny, zawierającego: optymalny podział godzin w każdym cyklu edukacyjnym, racjonalny przydział godzinowy zgodny z kwalifikacjami nauczycieli, bezpieczne i higieniczne warunki pracy oraz nauki,

$\rightarrow$ diagnozowanie lokalnych potrzeb edukacyjnych (katalog miejsc, zjawisk i osób, które można wykorzystać edukacyjnie),

$\rightarrow$ analizowanie możliwości, jakie dają programy nauczania,

$\rightarrow$ diagnozowanie wymagań uczniów ze specjalnymi potrzebami edukacyjnymi,

$\rightarrow$ umożliwienie podnoszenia umiejętności nauczycieli w ramach realizacji edukacji włączającej,

$\rightarrow$ ćwiczenie i wykorzystywanie umiejętności pracy zespołowej w codziennej praktyce szkolnej,

$\rightarrow$ zapewnienie prawidłowego przygotowania uczniów do egzaminu lub sprawdzianu,

$\rightarrow$ analizowanie potrzeb środowiska lokalnego w sferze edukacji, wychowania i kultury,

$\rightarrow$ kształcenie umiejętności związanych z poszerzeniem własnego warsztatu pracy.

Tworzenie strategii rozwoju szkoły musi opierać się na prowadzeniu dialogu, możliwie najbardziej szerokiego. Dialog nie może istnieć bez pokory, wiary w możliwość budowania i przebudowywania świata (Frerie 1993, s. 69-73). 
Rezultatami realizacji zadań związanych z rozwojem szkoły powinny być:

$\rightarrow$ porozumienie, współdziałanie, kompromis trzech podmiotów - uczniów, nauczycieli i rodziców - w dziele tworzenia systemu edukacji i rozwijania samorządności na terenie szkoły,

$\rightarrow$ rozwój jakościowy, czyli osiąganie lepszych wyników edukacyjnych,

$\rightarrow$ rozwój programowy, czyli poszerzenie oferty szkoły,

$\rightarrow$ rozwój osobowy kadry pedagogicznej, administracyjnej i obsługowej,

$\rightarrow$ rozwój bazy materialno-technicznej,

$\rightarrow$ współpraca ze środowiskiem lokalnym i z innymi szkołami,

$\rightarrow$ współpraca $z$ instytucjami i stowarzyszeniami w celu pozyskiwania środków zewnętrznych,

$\rightarrow$ współpraca $z$ władzami gminy i powiatu,

$\rightarrow$ dobrze skonstruowany plan nadzoru pedagogicznego i roczny plan pracy szkoły.

Myśląc o tworzeniu strategii placówki, musimy pamiętać, że jesteśmy ciągle w drodze. "Uczące się szkoły” są zdolne do zmiany, do nieustającego rozwoju, po to, by sprostać nowym wymaganiom pojawiającym się w szybko zmieniającym się społeczeństwie, zatem nie uczą się w nich tylko uczniowie, lecz cała społeczność szkolna (Hidebrandt 2001, s. 62).

\section{Planowanie pracy przedszkola}

Opracowując strategię przedszkola otwartego (inkluzyjnego), trzeba uświadomić sobie rolę i znaczenie planu pracy - tzw. planu bieżącego. Zawiera on określone zadania powierzone konkretnym osobom do realizacji w ustalonych terminach. Jest on uszczegółowieniem koncepcji, gwarantem osiągnięcia założonych priorytetów, drogą dojścia do celu. Plan nie może być konstrukcją zamkniętą, ale powinien być elastyczny i otwarty na zmiany, co w konsekwencji będzie miało przełożenie na jego wdrażanie i skuteczność. Ważne jest również, aby zawierał wszystkie obszary pracy przedszkola - od modułu wychowawczego i dydaktycznego po organizacyjno-finansowy. Optymalny czas jego realizacji wynosi rok lub dwa lata. Plan bieżący przedszkola jest uzupełniony o plany operacyjne, dotyczące niektórych działań, np. współpracy z rejonową szkołą podstawową. $Z$ reguły przyjmuje on formę harmonogramu, uwzględniającego ustalenia obu stron. 
W mojej ocenie struktura planu pracy placówki, której jestem dyrektorem, wypełnia definicję „planu bieżącego" oraz służy realizacji koncepcji przedszkola ukierunkowanego na inkluzję. Takie planowanie pozwala usystematyzować działania i uzyskać ich pełną przejrzystość. Umożliwia również natychmiastową identyfikację zagrożeń, zarówno przeze mnie, jak i przez pozostałych członków zespołu.

Jako dyrektor mam świadomość, że wszystkie nasze działania, niepowodzenia, sukcesy są wypadkową różnorodności - tworzymy społeczność niejednorodną pod względem wykształcenia, wieku i doświadczenia. Mamy różne pasje i zamiłowania. Naszym światopoglądom niejednokrotnie nie jest ze sobą „po drodze”. Spieramy się w wielu kwestiach, ale w wielu też się zgadzamy - jesteśmy zespołem, który może na sobie polegać, grupą uczącą się, o wysokich kwalifikacjach, reagującą na potrzeby „tu i teraz". Przykładem może być udział kadry pedagogicznej w kursie języka migowego, gdy pojawiło się u nas dziecko z bardzo dużym uszkodzeniem słuchu. Utożsamiamy się z misją i wizją placówki, które wspólnie wypracowaliśmy i które są naszym drogowskazem. Jesteśmy „przedszkolem daltońskim”, otwartym na każdą indywidualność oraz na wspólnotę, do której należy. Pracujemy w oddziałach zróżnicowanych wiekowo (od trzech do sześciu lat), do których uczęszczają dzieci z grup defaworyzowanych, m.in. z niepełnosprawnościami i ciężkimi chorobami: nowotworami, cukrzycą, z deficytem LCHAD (niedobór dehydrogenazy długołańcuchowych kwasów tłuszczowych), padaczką, astmą lekooporną, zespołem NBS1, chorobami serca, alkoholowym zespołem płodowym FAS, a także doświadczeniem migracji, z zaburzeniami zachowania oraz pochodzące z rodzin niepełnych. Zmieniliśmy sposób i organizację żywienia w przedszkolu - otworzyliśmy się na różnorodne jadłospisy, pozyskaliśmy do współpracy dietetyka. W ramach opieki specjalistycznej zatrudnieni są: logopeda, terapeuta i choreoterapeuta. Ich wszechstronna wiedza, doświadczenie, kreatywność i oddanie dzieciom są bezcenne w procesie włączania.

Kiedy zastanawiam się, co doprowadziło nas do tego miejsca, w którym jesteśmy, na myśl przychodzi mi tylko jedna odpowiedź - ludzie, ich wrażliwość, empatia, inteligencja, konsekwencja i odpowiedzialność. A także, a może przede wszystkim, ich umiejętność współpracy w zespole. Choć nadal jesteśmy w połowie drogi, ważne, że pokonujemy ją wspólnie. 
Na zakończenie przytoczę słowa, które stały się dla mnie podstawą "bycia nauczycielem i dyrektorem", wyznacznikiem mojego człowieczeństwa. Dały mi ogromną siłę do działania, jednocześnie uświadamiając, jak bardzo jestem niedoskonała. „ «Inny» tak jak dzieło sztuki zaprasza mnie do zobaczenia świata w innej perspektywie, do zobaczenia siebie jakby w innym świecie. Spotkanie $z$ «Innym» jest więc jednocześnie spotkaniem z samym sobą. Od «Innego", tak jak od tekstu, mogę uzyskać nowe rozumienie samego siebie, a zyskując nowe rozumienie samego siebie staję się tym samym otwartym na «Innych»" (Murzyn 1999, s. 25).

\section{Planowanie pracy szkoły}

Każdy dyrektor, planując pracę placówki edukacyjnej, musi być przekonany do:

$\rightarrow$ wizji szkoły - jaka ona ma być w dłuższej perspektywie czasowej,

$\rightarrow$ misji szkoły - kierunków przyszłych działań, których proces realizacji jest wiarygodny i odnosi się do rzeczywistości,

$\rightarrow$ celów szkoły - realizowania działań, nadania im jednolitego kierunku. Potrzebne jest to do planowania pracy w szkole, stanowi źródło motywacji dla pracowników i podstawę skutecznego mechanizmu oceny oraz kontroli.

Musi on również przygotować niezbędne dokumenty - plany:

$\rightarrow$ organizacyjne (plan nauczania, arkusz organizacji pracy szkoły, roczny plan pracy szkoły, plan nadzoru pedagogicznego i pracy zespołów),

$\rightarrow$ doskonalenia zawodowego,

$\rightarrow$ techniczne (zakup pomocy dydaktycznych, remontów itp.).

Dyrektor bierze pod uwagę to, że działania dydaktyczno-wychowawcze i zarządzanie szkołą muszą być zawsze przemyślane, zaplanowane i konsultowane z nauczycielami oraz z rodzicami. Areną do analizy potrzeb szkoły, rozwiązywania problemów, usprawniania kadry, wymiany doświadczeń będzie struktura zwana "doskonaleniem wewnątrzszkolnym". Czasem wymaga ona wsparcia środowiska lokalnego, a szczególnie rodziców, czyli najważniejszych osób decydujących o sposobie wychowania dzieci. Takie podejście pomoże w projektowaniu i przewidywaniu działań, przybliżając szkołę do życia. 
Przeprowadzając ewaluację swojej pracy, widzę, że dzięki dobremu planowaniu udało nam się stworzyć zespół, angażujący wszystkich pracowników szkoły: nie ma osoby niepotrzebnej, każdy ma swoje zadania w łańcuszku codziennych działań (Tarwacki 2011, s. 51). Planowanie pracy placówki musi odpowiadać potrzebom środowiska, w którym ona funkcjonuje. Dbając o wszystkie elementy układanki, jaką jest funkcjonowanie szkoły, a także szanując każdego uczestnika procesu edukacyjnego, można odnieść sukces. 